\title{
EFFECTS OF PRENYLATED ISOFLAVONES OSAJIN AND POMIFERIN IN PREMEDICATION ON HEART ISCHEMIA-REPERFUSION
}

\author{
Tomas Florian ${ }^{\mathrm{a}}$, Jiri Necas ${ }^{\mathrm{a} *}$, Lenka Bartosikova ${ }^{\mathrm{a}}$, Jarmila Klusakovac ${ }^{\mathrm{c}}$, Vaclav Suchy ${ }^{\mathrm{b}}$, \\ ElMoataz B. El Naggar ${ }^{\mathrm{a}}$, Eva Janostikova ${ }^{\mathrm{a}}$, Tomas Bartosik ${ }^{\mathrm{c}}$
}

\author{
a Department of Human Pharmacology and Toxicology, University of Veterinary and Pharmaceutical Sciences Brno, \\ Pharmaceutical Faculty, Palackeho 1-3, 61242 Brno, Czech Republic \\ ${ }^{b}$ Department of Natural Drugs, University of Veterinary and Pharmaceutical Sciences Brno, Pharmaceutical Faculty, \\ Palackeho 1-3, 61242 Brno, Czech Republic \\ c St. Anne Teaching Hospital Brno, Czech Republic \\ e-mail: necasj@vfu.cz
}

Received: February 6, 2006; Accepted: March 22, 2006

Key words: Machura pomifera/Isoflavones osajin and pomiferin/Heart ischemia-reperfusion/Free oxygen radicals

The present 15 days study was undertaken to evaluate the cardioprotective potential of the prenylated isoflavones osajin and pomiferin isolated from the infructences of Maclura pomifera, Moraceae, against ischemia-reperfusion induced injury in rat hearts as a model of antioxidant-based composite therapy. The study was performed on isolated, modified Langendorff-perfused rat hearts and the ischemia of heart was induced by stopping coronary flow for $30 \mathrm{~min}$

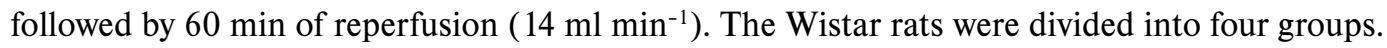

The first treatment group received osajin $(5 \mathrm{mg} / \mathrm{kg} /$ day in $0.5 \%$ Avicel $)$; the second treatment group received pomiferin $(5 \mathrm{mg} / \mathrm{kg} /$ day in $0.5 \%$ Avicel $)$; the placebo group received only 0.5 Avicel; the last was an untreated control group. Biochemical indicator of oxidative damage-lipid peroxidation product malondialdehyde, antioxidant enzymes - superoxide dismutase, glutathione peroxidase, total antioxidant activity in serum and myocardium were evaluated. The effect of osajin and pomiferin on cardiac function, left ventricular end-diastolic pressure, left ventricular pressure and peak positive $+\mathrm{dP} / \mathrm{dt}$ ischemia and reperfusion, also was examined.

The results demonstrate that osajin and pomiferin attenuates the myocardial dysfunction provoked by ischemiareperfusion. This was confirmed by an increase in both antioxidant enzyme values and total antioxidant activity. The cardioprotection provided by osajin and pomiferin treatment results from the suppression of oxidative stress and this correlates with improved ventricular function.

\section{INTRODUCTION}

The flavonoids are a heterogeneous group of phenolic compounds (approx. 4000), ubiquitus in the plant kingdom. They normally occur in the human diet, especially in fruit and vegetables, and their daily intake is cca $1-2 \mathrm{~g}$. Many positive as well as negative effects on plant and animal cells of flavonoids have been documented ${ }^{1-2}$. Many of their effects are significant ${ }^{3-5}$. In oncology the flavonoids are used as compounds, which reduce the side effects of cytostatics and on the other hand, they enhance the therapeutic effects. This field is documented very well ${ }^{6-8}$.

Flavonoids are often used in the treatment of inflammation because of their ability to inhibit the key enzyme in PG (prostaglandins) synthesis - $\mathrm{COX}^{9-11}$. They have been tested in post-transplantation conditions too ${ }^{12-13}$.

Flavonoids are effective antioxidants in the case of the oxidative injury ${ }^{14-15}$. They prevent lipid peroxidation, scavenge free oxygen radicals and inactivate pro-oxidative metal ions (iron, copper). The scavenging activity is one of the best-known properties and it represents a significant therapeutic use ${ }^{16-17}$. The antioxidant activity of the flavonoids depends on the number and position of hydroxyl groups in their molecules and on their glycosylation. Optimal properties were found in flavonoids with an ortho-hydroxy structure on ring B; 2, 3 double bond, and 4-oxo functional group in the ring $\mathrm{C}$, and 3 and $5-\mathrm{OH}$ groups on the rings $\mathrm{A}$ and $\mathrm{C}^{18}$.

In vitro studies of antioxidant abilities of osajin and pomiferin have revealed: the peroxinitrite and DPPH (diphenyl-picryl-hydrazyl) radical scavenging activity. The Fe(II)/NADPH enhanced lipid peroxidation test in the rat liver microsomal fraction was also performed. Mouse hepatic microsomes were used to determine the EROD activity (7-ethoxyresorufin-O-deethylase) of osajin and pomiferin ${ }^{19}$. In vivo studies confirmed the scavenging potential of osajin and pomiferin too ${ }^{20-21}$.

Among various reactive oxygen species (ROS) generated during pathological processes, which cause or accompany ischemia/reperfusion (I/R) injury, $\mathrm{O}^{-2 \bullet}$ plays the key role. In spite of being a free radical, it is not highly reactive. However the $\mathrm{O}^{-2 \bullet}$ radical anion appears to play a central role, since other reactive intermediates are formed in a reaction sequences starting with it. Since the physio- 
logical functions of heart are conditioned by a remarkable consumption of oxygen, the elimination of $\mathrm{O}^{-2 \bullet}$ radical during $\mathrm{I} / \mathrm{R}$ is one possible therapeutic intervention. In the presented study we have examined whether it is possible to affect the origination of $\mathrm{O}^{-2}$ and its metabolic derivates experimentally during the heart I/R secondary to the 15 days oral administration ( $5 \mathrm{mg} / \mathrm{kg} /$ day) of flavonoids osajin or/and pomiferin.

\section{MATERIAL AND METHODS}

\section{Extract preparation}

Ground fruit of Maclura pomifera, Moraceae, was subjected to consecutive Soxhlet extraction using methanol, yield yellow crystals of osajin-pomiferin mixture after cooling. The crystals were filtered, washed and dissolved in hot methanol.

Pomiferin was separated from osajin by the addition of lead acetate which reacts with the two hydroxyl groups at position 3 and 4 on ring $B$ of pomiferin to form a light yellow insoluble coagulate while osajin remains in solution since it has only one hydroxyl group on ring B. Osajin was then further re-crystallized from the methanolic solution after concentration under vacuum.

\section{Separation procedure}

10 grams of osajin/pomiferin crystals were dissolved in $200 \mathrm{ml}$ of hot methanol and then mixed with 15 grams of lead acetate trihydrate (dissolved in $20 \mathrm{ml}$ methanol). The light yellow coagulate created over night was filtered and then rinsed with hot acetone.

Osajin and pomiferin were obtained by re-crystallization from the thickened methanol and acetone solutions.

For the purpose of identification and purity ascertainment of osajin and pomiferin during all the extraction process, reversed phase high performance liquid chromatography was performed.<smiles>CC(C)=CCc1c2c(c3occ(-c4ccc(O)c(C)c4)c(=O)c3c1O)C=CC(C)(C)O2</smiles><smiles>CC(C)=CC/C(C(O)=C1COC=C(c2ccc(O)c(O)c2)C1=O)=C1/CC=CC(C)(C)O1</smiles>

Fig. 1. Chemical structure of osajin and pomiferin.

\section{Reversed phase high performance liquid chromatography}

The HPLC (HP 1100) system consists of quaternary pump, autosampler, thermostatic column compartment, and diode array detector. The analytical column was Supelcosil ABZ+Plus and LC-8, $15 \mathrm{~cm} \times 4.6 \mathrm{~mm}$, $3 \mu \mathrm{m}$. The mobile phase consisted of two eluents, (A) acetonitrile and (B) $40 \mathrm{mM}$ formic acid. Separation of compounds was carried out with gradient elution profile: $1^{\text {st }}$ min, $70: 30$, during $15 \mathrm{~min}, 100: 0$. Chromatography was performed at $40{ }^{\circ} \mathrm{C}$ with a flow-rate of $1.0 \mathrm{ml} / \mathrm{min}$, and detection was at $280 \mathrm{~nm}$ and $350 \mathrm{~nm}$.

\section{Animals and therapy}

The study and its experimental protocol were approved and monitored by the Ethics Committee of the University of Veterinary and Pharmaceutical Sciences in Brno. The state of health of all animals was inspected regularly several times a day both during the acclimation of the animals and in the course of the whole experiment performed by the work group whose members are holders of the Eligibility Certificate issued by the Central Commission for Animal Protection pursuant to Section 17 of the Czech National Council Act No 246/1992 Coll. on animal protection against maltreatment.

This study was performed on 40 male Wistar SPF (AnLab, Germany) laboratory rats of identical age (6 month) and comparable weight $(354 \pm 27 \mathrm{gr})$. The animals were housed at a standard controlled temperature, fed a standard diet for small laboratory animals, and given water ad libitum. After a recovery period, the animals were divided randomly into 4 groups (ten rats in each group):

The first group-treated group-received osajin daily at a dose of $5 \mathrm{mg} . \mathrm{kg}^{-1}$ in $2 \mathrm{ml}$ of $0.5 \%$ Avicel solution orally by intragastric tube, the second-treatment group-received pomiferin daily at a dose of $5 \mathrm{mg} . \mathrm{kg}^{-1}$ in $2 \mathrm{ml}$ of $0.5 \%$ Avicel solution orally by intragastric tube ${ }^{22}$. The third the placebo group - received only $0.5 \%$ Avicel in the same quantity $(2 \mathrm{ml})$ and by the same application method as in the treated group. The last group of the animals received no treatment or Avicel.

\section{Experimental design}

At the end of the treatment period (15 days) rats were anesthetized with an intraperitoneal injection of anaesthetic ( $2 \%$ Rometar $0.5 \mathrm{ml}+1 \%$ Narkamon $10 \mathrm{ml}$, dose $0.5 \mathrm{ml}$ solution/100 g body weight) and after intraperitoneal administration of heparine injection of 500 IU dose, the heart were excised and perfused. In all experiment, modified Langendorff method and the universal apparatus Hugo Sachs Electronic UP 100 (Germany HSE) was used. Working schedule: stabilization/ischemia/reperfusion proceeded at intervals of 10/30/60 min. The evaluated blood biochemical parameters: malondialdehyde (MDA) serum values - TBARs method, total antioxidant activity (TAA), glutathion peroxidase (GSHPx), superoxide dismutase (SOD), using RANDOX testing kits (Dublin, Ireland).

Biomechanical parameters from isolated heart: left ventricle pressure (LVP), end-diastolic pressure (LVEDP), 


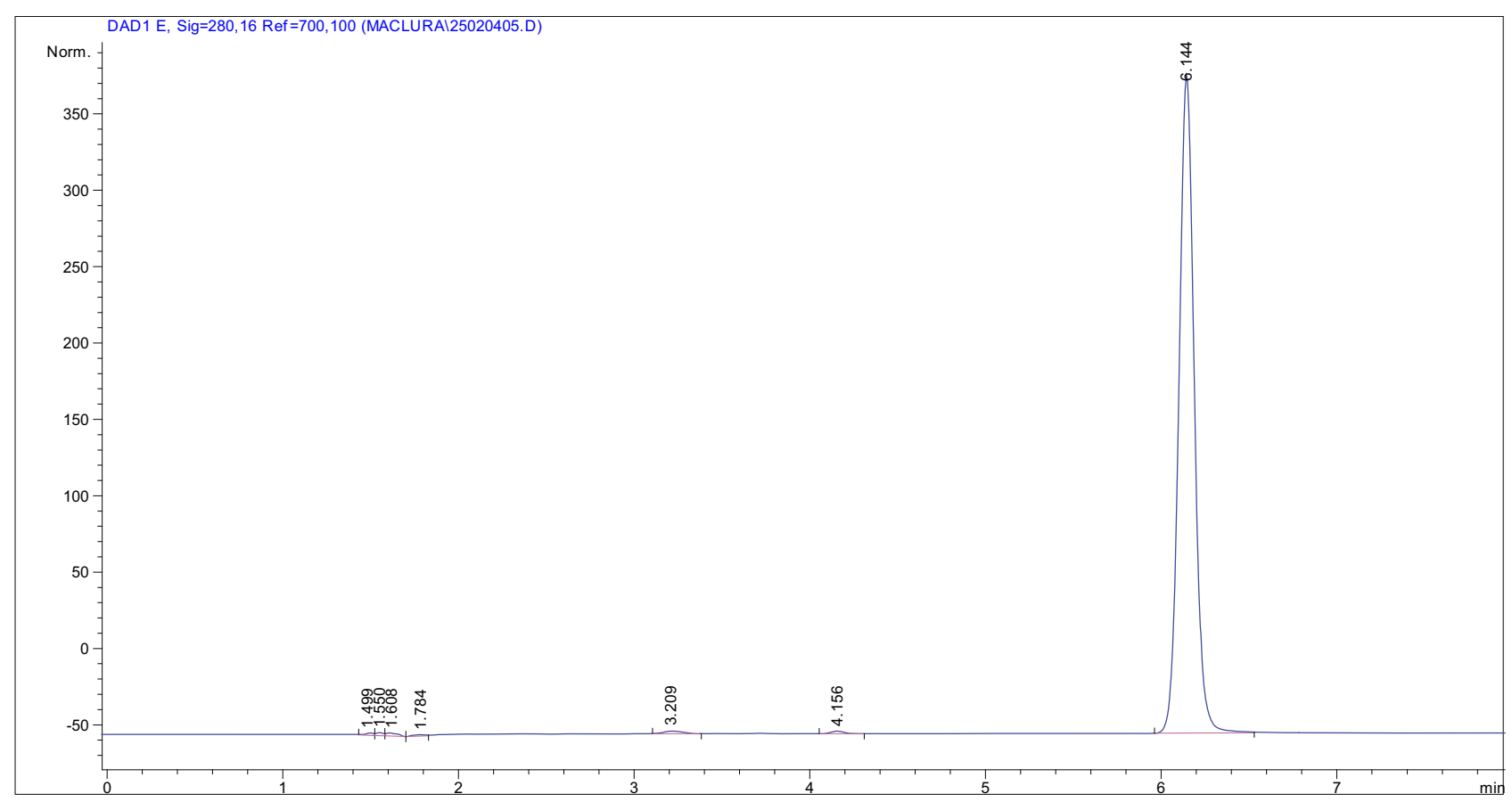

Fig. 2. High-performance liquid chromatogram of osajin from infructencence of Maclura pomifera, Moraceae. (LC-8 - method Maclura).

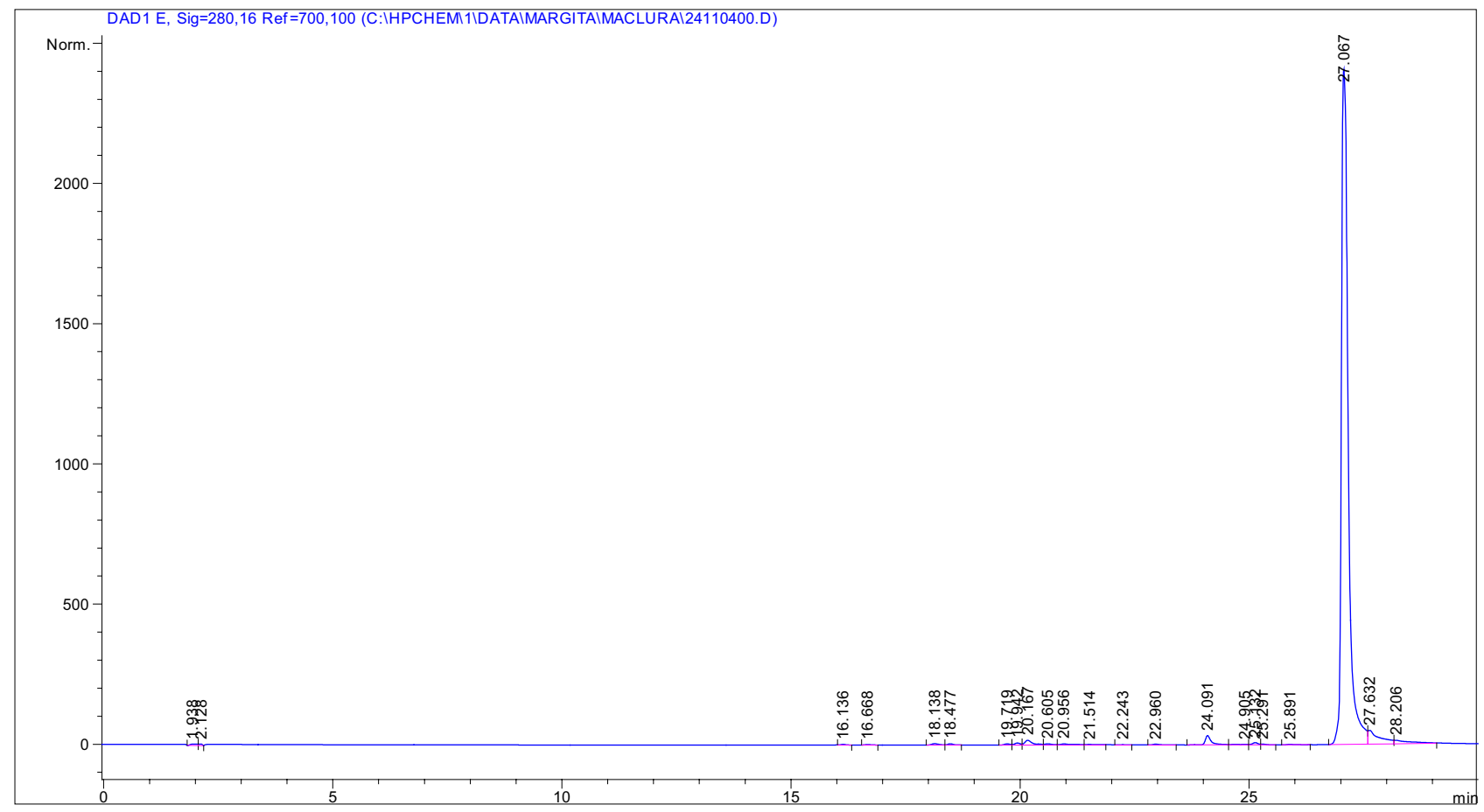

Fig. 3. High-performance liquid chromatogram of pomiferin from infructencence of Maclura pomifera, Moraceae (Supelcosil ABZ+Plus, method Muscar).

contractility $\left(\mathrm{dP} / \mathrm{dt}_{\max }\right)$ were measured using a ball filled with liquid $(8-12 \mathrm{mmHg})$, inserted through the left atrium in the left ventricle connected to the analog convertor (Isotec HSE, DIF modul HSE) ${ }^{23}$. After reperfusion, the heart was cooled in liquid nitrogen and stored at a temperature $-80^{\circ} \mathrm{C}$ for further analyses. Lipoperoxidation assessment: in supernatant of the heart homogenizator in saline, the TBARS value was assessed by the spectroscopic method ${ }^{24}$. Antioxidant enzyme activities: cellular GSH peroxidase (GSHPx) activity ${ }^{25-26}$; cellular SOD activity $^{27-28}$. 
Table 1. Effect of osajin and pomiferin application on MDA serum values, total antioxidant activity and activity of enzymes participating in scavenging reactions.

\begin{tabular}{|c|c|c|c|c|}
\hline $\begin{array}{l}\text { Animal groups } \\
\quad(\mathbf{n}=\mathbf{1 0})\end{array}$ & $\begin{array}{c}\text { MDA } \\
(\mathrm{mmol} / \mathrm{L})\end{array}$ & $\begin{array}{c}\text { TAA } \\
(\mathrm{mmol} / \mathrm{L})\end{array}$ & $\begin{array}{l}\text { SOD } \\
(\mathrm{U} / \mathrm{ml})\end{array}$ & $\begin{array}{l}\text { GSHPx } \\
(\mu \mathrm{kat} / 1)\end{array}$ \\
\hline $\begin{array}{c}\text { Treated with } \\
\text { osajin }(5 \mathrm{mg} / \mathrm{kg} / \text { day })\end{array}$ & $\begin{array}{c}0.80 \pm 0.08 \\
* *++\end{array}$ & $\begin{array}{c}0.49 \pm 0.03 \\
* *++\end{array}$ & $\begin{array}{c}232.23 \pm 17.62 \\
* *++\end{array}$ & $\begin{array}{c}1569.48 \pm 133.93 \\
* *++\end{array}$ \\
\hline $\begin{array}{c}\text { Treated with } \\
\text { pomiferin }(5 \mathrm{mg} / \mathrm{kg} / \mathrm{day})\end{array}$ & $\begin{array}{c}0.89 \pm 0.11 \\
* *++\end{array}$ & $\begin{array}{c}0.52 \pm 0.05 \\
* *++\end{array}$ & $\begin{array}{c}227.98 \pm 19.21 \\
* *++\end{array}$ & $\begin{array}{c}1619.81 \pm 146.23 \\
* *++\end{array}$ \\
\hline Placebo group & $1.77 \pm 0.12$ & $0.41 \pm 0.04$ & $70.39 \pm 2.79$ & $1229.10 \pm 120.45$ \\
\hline Control group & $1.89 \pm 0.16$ & $0.43 \pm 0.03$ & $67.37 \pm 3.97$ & $1121.37 \pm 152.21$ \\
\hline
\end{tabular}

$* * \mathrm{p} \leq 0.01$ treated vs placebo group

$++\mathrm{p} \leq 0.01$ treated vs control group

Table 2. Values of myocardial MDA, and activity GSHPx and SOD.

\begin{tabular}{|c|c|c|c|}
\hline Animal groups (n=10) & $\begin{array}{c}\text { MDA } \\
(\mathrm{nmol} / \mathrm{mg} \text { protein })\end{array}$ & $\begin{array}{c}\text { GSHPx } \\
(\mathrm{nmol} / \mathrm{min} / \mathrm{mg} \text { protein })\end{array}$ & $\begin{array}{c}\text { SOD } \\
(\mathrm{U} / \mathrm{mg} \text { protein })\end{array}$ \\
\hline $\begin{array}{c}\text { Treated with } \\
\text { osajin (5 } \mathbf{~ m g / k g / d a y ) ~}\end{array}$ & $\begin{array}{c}2.67 \pm 0.21 \\
* *++\end{array}$ & $62.0 \pm 2.5$ & $\begin{array}{c}6.7 \pm 0.5 \\
*+\end{array}$ \\
\hline $\begin{array}{c}\text { Treated with } \\
\text { pomiferin } \mathbf{5} \mathbf{~ m g / k g / d a y )}\end{array}$ & $\begin{array}{c}3.26 \pm 0.23 \\
*+\end{array}$ & $63.1 \pm 2.3$ & $\begin{array}{c}6.4 \pm 0.6 \\
*+\end{array}$ \\
\hline Placebo group & $4.55 \pm 0.15$ & $65.5 \pm 5.0$ & $5.6 \pm 0.6$ \\
\hline Control group & $4.71 \pm 0.19$ & $68.0 \pm 4.0$ & $5.8 \pm 0.7$ \\
\hline
\end{tabular}

$* * \mathrm{p} \leq 0.01$ treated vs placebo group

$++\mathrm{p} \leq 0.01$ treated vs intact group

$* \mathrm{p} \leq 0.05$ treated vs placebo group $\quad+\mathrm{p} \leq 0.05$ treated vs intact group

\section{Preparation of rat heart homogenate and measured biochemical parameters}

Tissue homogenate was prepared in a ratio of $1 \mathrm{~g}$ of wet tissue to 10 times (w/v) 0.05 M-ice cold phosphate buffer (ph 7.4) and homogenized using DI 25 Basic, Germany homogenizer. Myocardial thiobarbituric acid reactive substances (TBARS) a marker of lipid peroxidation, and endogenous antioxidants e.g. superoxide dismutase (SOD) ${ }^{25-26}$ and glutathione peroxidase (GSHPx) $)^{27-28}$ were measured in all the groups.

\section{Lipid peroxidation assay}

The lipid peroxidation was assessed by studying thiobarbituric acid reactive substances (TBARS) by the method described by Buege and Aust ${ }^{24}$. Aliquots of the supernatant were added to a pyrex tube that contained trichloracetic acid (10\%) and thiobarbituric acid (0.67\%) and incubated at $100{ }^{\circ} \mathrm{C}$ for 15 minutes. The mixture was allowed to cool on ice for $5 \mathrm{~min}$. This was followed by the addition of $1.5 \mathrm{ml}$ of butyl-alcohol; the mixture was vigorously agitated for $40 \mathrm{~s}$ and centrifuged at $1000 \mathrm{~g}$ for
15 min to extract the resulting chromogen. The TBARS value was assessed by the spectroscopic method (spectrophotometer Unicam UV 300, GB) at absorbance $532 \mathrm{~nm}$ and calculated using the coefficient $1.56 \times 105 \mathrm{M}^{-1} \mathrm{~cm}^{-1}$, expressed as nmol MDA/g of tissue. Commercially available malondialdehyde was used as a standard.

\section{Antioxidant enzyme activities}

Assay of cellular GSH peroxidase activity.

Cellular GSH peroxidase (GSHPx) activity was measured by the method of Flohé and Gunzler ${ }^{25}$ and $\mathrm{Kakkar}^{26}$. Briefly, to an assay cuvette containing $0.5 \mathrm{ml}$ of $50 \mathrm{mM}$ potassium phosphate ( $\mathrm{pH} 7.0$ ), 1mM EDTA, and $2 \mathrm{mM}$ sodium azide, $100 \mu \mathrm{l}$ of sample, $100 \mu \mathrm{l}$ of $10 \mathrm{mM} \mathrm{GSH}$, $100 \mu \mathrm{l}$ of glutathione reductase $(2.4 \mathrm{U} / \mathrm{ml})$, and $100 \mu \mathrm{l}$ of $1.5 \mathrm{mM}$ NADPH were added. The cuvette was incubated at $37{ }^{\circ} \mathrm{C}$ for $3 \mathrm{~min}$. After the addition of $100 \mu \mathrm{l}$ of $2 \mathrm{mM}$ $\mathrm{H}_{2} \mathrm{O}_{2}$, the rate of NADPH consumption was monitored at $340 \mathrm{~nm}, 37^{\circ} \mathrm{C}$ for $5 \mathrm{~min}$. This was designated as the total rate of NADPH consumption. The non-enzyme dependent consumption of NADPH was also measured 
as above except that the $100 \mu 1$ of sample was replaced by $100 \mu \mathrm{l}$ of sample buffer. The rate of enzyme-dependent NADPH consumption was obtained by subtracting the non-enzyme-dependent NADPH consumption rate from the total NADPH consumption rate. GSHPx activity was calculated using the extinction coefficient of 6.22 $\mathrm{mM}^{-1} \mathrm{~cm}^{-1}$ and expressed as nanomoles of NADPH consumed per min per milligram of cellular protein.

\section{Assay of cellular SOD activity.}

Total cellular SOD activity was determined by the method of Spitz and Oberley ${ }^{27}$ with slight modifications by Wende ${ }^{28}$. Briefly, the reaction mix (to be prepared freshly) contained in $50 \mathrm{mM}$ potassium phosphate buffer, $\mathrm{pH} 7.8,1.33 \mathrm{mM}$ diethylenetriaminepentaacetic acid, $1.0 \mathrm{U} / \mathrm{ml}$ catalase, $70 \mu \mathrm{M}$ nitroblue tetrazolium, $0.2 \mathrm{mM}$ xanthine, $0.05 \mathrm{mM}$ bathocuproinedisulfonic acid, and $0.13 \mathrm{mg} / \mathrm{ml} \mathrm{BSA}$. As much as $0.8 \mathrm{ml}$ of the reaction mix was added to each cuvette, followed by addition of 100 $\mu \mathrm{l}$ of sample. The cuvettes were pre-warmed at $37^{\circ} \mathrm{C}$ for $3 \mathrm{~min}$. The reaction was then started by adding $100 \mu \mathrm{l}$ of XO $(0.1 \mathrm{U} / \mathrm{ml})$. The formation of formazan blue was monitored at $560 \mathrm{~nm}, 37^{\circ} \mathrm{C}$ for $5 \mathrm{~min}$. The sample total SOD activity was calculated using a concurrently run SOD (Sigma Chemical) standard curve and expressed as units per milligram of cellular protein.

\section{Statistical analysis}

The obtained values of the studied biochemical parameters were processed by the Microsoft ${ }^{\circledR}$ Excel table processor and statistically evaluated using UNISTAT programme, ANOVA test and unpaired Student's t-test. All values are expressed as mean $\pm \mathrm{SE}$. Statistical differences with a value $\mathrm{p} \leq 0.05$ were considered significant.

\section{RESULTS}

\section{Biochemical results - blood}

After the oral administration of osajin and pomiferin for a period of 15 days, MDA values were found to be significantly ( $\mathrm{p} \leq 0.01$ ) decreased in treated groups compared to the placebo or control animal groups $(0.80 \pm$ 0.08 and $0.89 \pm 0.11$ v.s. $1.77 \pm 0.12$ and $1.87 \pm 0.16)$.

The serum TAA values were significantly ( $\mathrm{p} \leq 0.01$ ) reduced in the placebo and control animal groups in comparison to that of the osajin and pomiferin-treated groups $(0.41 \pm 0.04$ and $0.43 \pm 0.03$ v.s. $0.49 \pm 0.03$ and $0.52 \pm$ $0.05)$. The results of MDA and TAA assays are summarized in the Tab. 1.

The superoxide dismutase (SOD) values were significantly ( $\mathrm{p} \leq 0.01$ ) highly increased in the treated animals groups compared to the placebo or control animal groups $(232.23 \pm 17.62$ and $227.98 \pm 19.21$ v.s. $70.39 \pm 2.79$ and $67.37 \pm 3.97)$.

The GSHPx values were significantly ( $\mathrm{p} \leq 0.01$ ) increased in the treated animals compared to that of the placebo or control animal groups (1569.48 \pm 133.93 and $1619.81 \pm 146.23$ v.s. $1229.10 \pm 120.45$ and $1121.37 \pm$
152.21). The results of SOD and GSHPx assays are summarized in the Table 1.

\section{Biochemical results - heart}

Myocardial MDA, activity of myocardial GSHPx and activity of myocardial SOD

There was a significant decrease in myocardial MDA in osajin ( $\mathrm{p} \leq 0.01)$ and pomiferin $(\mathrm{p} \leq 0.05)$ treated groups compared to that of placebo or control groups $(2.67 \pm 0.21$ and $3.26 \pm 0.23$ v.s. $4.55 \pm 0.15$ and $4.71 \pm$ $0.19 \mathrm{nmol} / \mathrm{mg}$ protein). No significant change was noted in myocardial MDA between placebo and control groups $(4.55 \pm 0.15$ vs. $4.71 \pm 0.19 \mathrm{nmol} / \mathrm{mg}$ protein $)$.

There was no significant change in myocardial GSHPX activity between treated, placebo and control groups respectively $(62.0 \pm 2.5$ and $63.1 \pm 2.3$ v.s. $65.5 \pm 5.0$ and $68.0 \pm 4.0)$.

There was a significant $(\mathrm{p} \leq 0.05)$ reduction in myocardial SOD activity in placebo or control group when compared to that of treated group $(5.6 \pm 0.6$ and $5.8 \pm$ 0.7 v.s. $6.7 \pm 0.5$ and $6.4 \pm 0.6$ units $/ \mathrm{mg}$ protein). No significant change was noted in myocardial SOD between placebo and control group (5.6 \pm 0.6 vs. $5.8 \pm 0.7$ units/ mg protein). See Tab. 2.

\section{Biomechanical results}

Fig. 4 shows the effect of osajin and pomiferin on LVP during ischemia and reperfusion. In hearts from placebo and control animals LVP recovered to $64 \pm 7$ and $65 \pm$ $6 \%$ of preischemic values at the end of the reperfusion. While hearts from the osajin and pomiferin pretreated animals, showed significantly improved postischemic recovery, reaching LVP values of $98 \pm 8 \%$ and $96 \pm 8 \%$ at the end of the reperfusion.

Fig. 5 shows the changes elicited in the osajin and pomiferin pretreated animals. In hearts from placebo and control animals LVEDP rise from $10.0 \pm 0.5 \mathrm{mmHg}$ to 44 \pm 3 and $43 \pm 4 \mathrm{mmHg}$ after $60 \mathrm{~min}$ of reperfusion. This increase was diminished in the hearts of the osajin and pomiferin pretreated animals. LVEDP was only $30 \pm 2$ and $32 \pm 2 \mathrm{mmHg}$ at the end of reperfusion.

Fig. 6 shows the effect of osajin and pomiferin on $\mathrm{dP} /$ $\mathrm{dt}_{\max }$ during ischemia and reperfusion. The pretreatment with osajin and pomiferin improved $+\mathrm{dP} / \mathrm{dt}_{\text {max }}$ recovery during reperfusion to $93 \pm 4 \%$ and $91 \pm 10 \%$ at 60 min of reperfusion. These values were significantly greater than those obtained from the placebo and control hearts (73 \pm 5 and $72 \pm 4 \%)$.

\section{DISCUSSION}

All biological systems are permanently in contact with reactive oxygen or nitrogen species (ROS/RNS) - so-called free radicals. These come from external sources or originate endogenously during physiological processes. The delicate balance between the cellular antioxidant defence and the generation of ROS is important for maintaining homeostasis. An imbalance in the oxidant-antioxidant ac- 


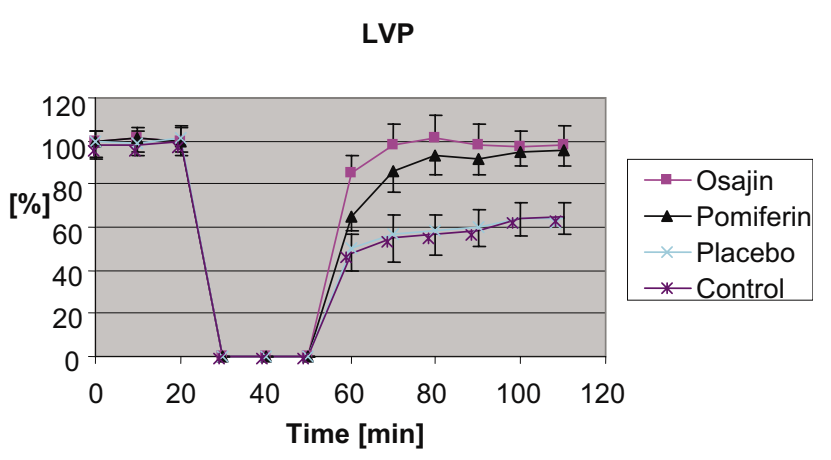

Fig. 4. Left ventricular pressure (\%).

tivity is called oxidative stress and may lead to many free radical mediated pathologies.

ROS play an important role in the pathogenesis of an ischemia/reperfusion (I/R) injury to the heart.

Oxygen is critical to myocardial cell aerobic metabolism and maintenance of high-energy stores for normal myocardial function. Acute ischemia results in a spectrum of disorders, which range from transient reversible stunning of the myocardium, to severe irreversible abnormalities. Ischemia-reperfusion injury is a complex process; the excessive production of oxygen-free radicals is the main mechanism involved in I/R injury ${ }^{29}$. In the heart, oxygen radicals may be generated by several mechanisms, such as mitochondrial respiration, activated neutrophils and, in some species, by xanthine oxidase activity. The release of free radicals $\left(\mathrm{O}^{-2 \bullet}\right.$ and $\left.\mathrm{OH}^{-\bullet}\right)$ in the early phase of reperfusion, in combination with the I/R-induced decrease an antioxidant activity, renders the myocardium extremely vulnerable ${ }^{16}$. The fact that the free oxygen radicals play a significant role during the heart $\mathrm{I} / \mathrm{R}$ is well known, being accompanied by SOD, GSHPx depletion and reduction of TAA which acts as natural oxygen radical scavengers in the organism ${ }^{17}$.

The aim of the performed study was assessment of the cardioprotective effect of the flavonoids osajin and pomiferin separated from Maclura pomifera, Moraceae ${ }^{3}$. The effects of osajin and pomiferin were studied on ischemiareperfusion injury in rats as a model of antioxidant-based composite therapy.

Antioxidant protection under conditions of induced oxidative injury is a complex system in which the separate antioxidant elements co-operate with one another. The function of one antioxidant often conditions the effects of another element in the system. Dismutation of $\mathrm{O}^{-2}$ by SOD is the first step of the enzymatic cascade leading to the complete detoxification of free radicals. However the product of its activity, $\mathrm{H}_{2} \mathrm{O}_{2}$, is still a toxic agent. The second step corresponds to the transformation of $\mathrm{H}_{2} \mathrm{O}_{2}$ to $\mathrm{H}_{2} \mathrm{O}$ via hydroperoxidases such as catalase or glutathione peroxidase (GSHPx).

The superoxide dismutase (SOD) serum values were statistically highly significantly $(p \leq 0.01)$ increased in the treated animals compared to that of the placebo and control animal groups $(232.23 \pm 17.62$ and $227.98 \pm 19.21$
LVEDP

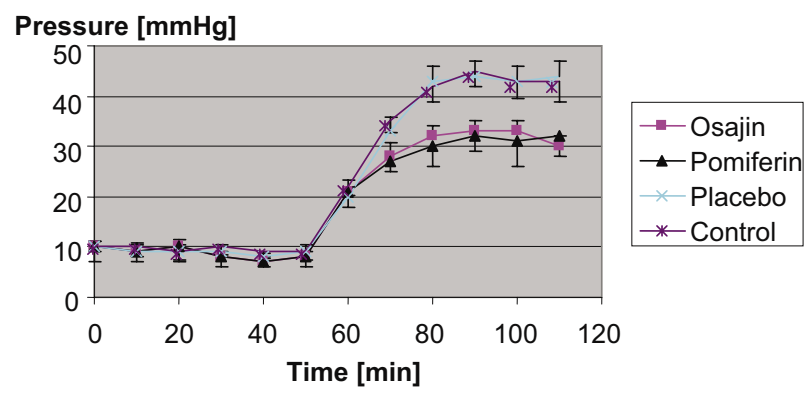

Fig. 5. Left ventricular end-diastolic pressure $(\mathrm{mmHg})$.

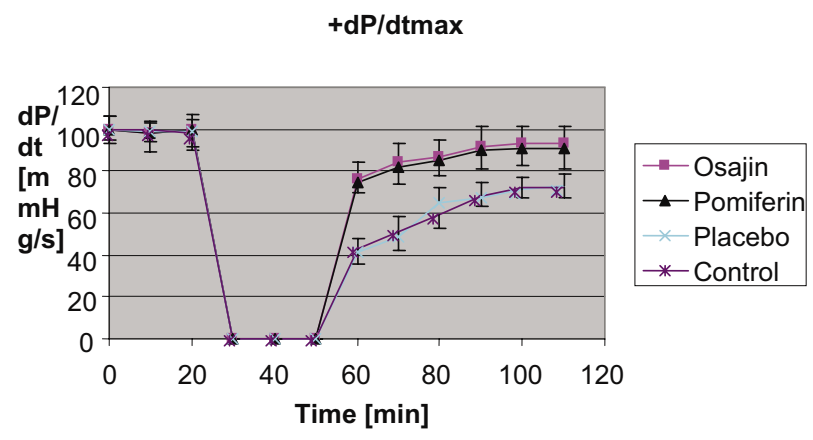

Fig. 6. Myocardial contractility (\%).

v.s. $70.39 \pm 2.79$ and $67.37 \pm 3.97$ ). There was a significant $(p \leq 0.05)$ reduction in myocardial activity of SOD in placebo and control group compared to that of the treated group $(6.7 \pm 0.5$ and $6.4 \pm 0.6$ v.s. $5.6 \pm 0.6$ and $5.8 \pm 0.7$ units/mg protein). No significant change was noted in myocardial SOD between placebo and control groups (5.6 \pm 0.6 vs. $5.8 \pm 0.7$ units $/ \mathrm{mg}$ protein).

It is evident that the increase of the SOD activity can be noxious for the organism. Since it can produce $\mathrm{H}_{2} \mathrm{O}_{2}$ (a precursor of the hydroxyl radical) at a rate in excess of that at which hydroperoxidases can remove it.

The GSHPx values were highly significantly $(\mathrm{p} \leq 0.01$ ) increased in the treated animals in comparison with the placebo and the control animal groups (1569.48 \pm 133.93 and $1619.81 \pm 146.23$ v.s. $1229.10 \pm 120.45$ and $1121.37 \pm$ 152.21). There were no significant changes in myocardial GSHPx activity in the treated, placebo or control animal groups, respectively $(62.0 \pm 2.5$ and $63.1 \pm 2.3$ v.s. $65.5 \pm$ 5.0 and $68.0 \pm 4.0)$.

GSHPx is only able to act in the presence of sufficient amount of reduced glutathione (GSH). GSH is oxidized to GSSG, and then GSSG (oxidized glutathione) can be reduced to (GSH) by the NADPH - dependent flavoenzyme glutathione reductase in order to maintain GSHPx activity. Thus, the ratio of GSSG to GSH is believed to be an excellent antioxidant marker during intracellular oxidative stress.

Natural antioxidants can react with various radicals through different mechanisms; they can affect one an- 
other (synergy, inhibition). Therefore we measured the total antioxidant activity, which quantifies the capacity of radical elimination in a biological material sample. After 15 days of osajin and pomiferin per-oral administration the total antioxidant activity serum values were statistically significantly ( $\mathrm{p} \leq 0.01)$ reduced in the placebo and control animal groups in comparison with the treated groups $(0.41 \pm 0.04$ and $0.43 \pm 0.03$ v.s. $0.49 \pm 0.03$ and $0.52 \pm 0.05)$.

After the 15 days oral administration of osajin and pomiferin at the dose of $5 \mathrm{mg} / \mathrm{kg}$, the serum MDA values were significantly $(\mathrm{p} \leq 0.01)$ decreased in treated groups compared to that of the placebo and control animals $(0.80$ \pm 0.08 and $0.89 \pm 0.11$ v.s. $1.77 \pm 0.12$ and $1.89 \pm 0.16$ ).

MDA, as a final product and a marker of free hydrogen radical metabolism generated during the pathological reactions following $\mathrm{I} / \mathrm{R}$, was significantly ( $\mathrm{p} \leq 0.01$; $p \leq 0.05$ ) reduced in the myocardium of the osajin and pomiferin treated groups compared to that of placebo and control group $(2.67 \pm 0.21$ and $3.26 \pm 0.23$ v.s. 4.55 \pm 0.15 and $4.71 \pm 0.19 \mathrm{nmol} / \mathrm{mg}$ protein). No significant changes were observed in the myocardial levels of MDA between placebo and control groups $(4.55 \pm 0.15$ v.s. 4.71 $\pm 0.19 \mathrm{nmol} / \mathrm{mg}$ protein).

Our results confirmed that there was a significant decrease in the myocardial MDA values in osajin and pomiferin treated groups compared to that of the placebo and control animal groups by which it confirmed the capacity to prevent lipoperoxidation induced by $\mathrm{I} / \mathrm{R}$ injury.

The findings from serum and myocardium supported the functional changes in treated hearts in comparison with placebo and control groups.

In hearts from placebo and control animals LVP recovered to $64 \pm 7$ and $65 \pm 6 \%$ of preischemic values at the end of the reperfusion. In the osajin and pomiferin pretreated animals the hearts showed significantly improved postischemis recovery, reaching LVP values of $98 \pm 8$ and $96 \pm 8 \%$ at the end of the reperfusion.

In hearts from placebo and control animals LVEDP rose from $10.0 \pm 0.5$ to $44 \pm 3$ and $43 \pm 4$, respectively $\mathrm{mmHg}$ after $60 \mathrm{~min}$ of reperfusion. This increase was diminished in the hearts from the osajin and pomiferin pretreated animals to $30 \pm 2$ and $32 \pm 2 \mathrm{mmHg}$ at the end of reperfusion.

The pretreatment with osajin and pomiferin improved $+\mathrm{dP} / \mathrm{dt}_{\text {max }}$ recovery during reperfusion to $93 \pm 4$ and $91 \pm 10 \%$ at $60 \mathrm{~min}$ of reperfusion. These values were significantly greater then those obtained from placebo and control hearts ( $73 \pm 5$ and $72 \pm 4 \%$ ).

From the results of our experiment it can be deduced that the administration of osajin and pomiferin in laboratory rats has a cardioprotective potential against ischemiareperfusion induced injury in rat hearts as a model of antioxidant-based composite 15 days therapy. This was confirmed by the increase in both the antioxidant enzyme values and the total antioxidant activity that occur even at the dose $5 \mathrm{mg} / \mathrm{kg} /$ day. This effect is also demonstrated in the functional parameters of hearts - LVP, LVEDP, and $+\mathrm{dP} / \mathrm{dt}_{\max }$.
In conclusion, the results from the present study suggest that the prenylated isoflavones osajin and pomiferin have a potent cardioprotective effects in prefused rat hearts subjected to global ischemia and reperfusion. Its effects may be mediated through the inhibition of lipid peroxidation.

Isoflavones osajin and pomiferin can antagonize myocardial injury induced by $\mathrm{I} / \mathrm{R}$ through inhibiting oxidative stress. In this work, pre-treatment with osajin and/ or pomiferin at the doses of $5 \mathrm{mg} / \mathrm{kg} /$ day, significantly decreased the myocardial lipid peroxide production of MDA and indicated that osajin and pomiferin could have an inhibiting effect on oxidative stress induced by $I / R$. Although the isoflavones osajin and pomiferin seem to be protective with a probable effect against the oxidative injury induced by the heart $\mathrm{I} / \mathrm{R}$, their effects and optimal method of application have to be explored further.

\section{REFERENCES}

1. Rice-Evans C. (1995) Plant polyphenols: free radical scavengers or chain-breaking antioxidants? Biochem Soc Symp 61, 103-116

2. Van Hoorn DEC, Nijveldt RJ, Van Leeuwen PAM, Hofman Z, M'rabet L, De Bont DBA, Norren KV. (2002) Accurate prediction of xanthin oxidase inhibition based on the structure of flavonoids. Eur J Pharmacol 451, 111-118

3. Lee SJ, Wood AR, Maier CGA, Dixon RA, Mabry TJ. (1998): Prenylated flavonoids from Maclura pomifera. Phytochemistry 49, 2573-2577

4. Havsteen BH. (2002) The biochemistry and medical significance of the flavonoids. Pharmacol Therapeut 96, 67-202

5. Rao YK, Fang SH, Tzeng YM. (2005) Anti-inflammatory activities of flavonoids isolated from Caesalpinia pulcherrima. J Ethnopharmacol 100, 249-253

6. Kandaswami C, Perkins E, Soloniuk DS, Drzewiecki G, Middleton E Jr. (1991): Antitproliferative effects of citrus flavonoids on a human squamous - cell carcinoma in vitro. Cancer Lett 56, 147152

7. Nishino H, Tokuda H, Satomi Y, Masuda M, Osaka Y, Yogosawa S, Wada S, Mou XY, Takayasu J, Murakoshi M, Jinnno K, Yano M. (2004) Cancer prevention by antioxidants. Biofactors 22, 57-61.

8. Scambia G, Ranelletti FO, Panici PB, Piantelli M, Bonanno G, De Vincenzo R, Ferrandina G, Maggiano N, Capelli A, Mancuso S. (1992) Inhibitory effect of quercetin on primary ovarian and endometrial cancers and synergistic activity with cis-diamminedichloroplatinum. Gynecol Oncol 45, 13-19

9. O’Leary KA, de Pascual-Tereasa S, Needs PW, Bao YP, O'Brien NM, Williamson G. (2004) Effect of flavonoids and Vitamin E on cyclooxygenase-2 (COX-2) transcription. Mutat Res-Fund Mol 551, 245-254

10. Seaver B, Smith JR. (2004) Inhibition of COX isoforms by nutraceuticals. J Herb Pharmacother 4, 11

11. Selvam C, Jachak SM, Bhutani KK. (2004) Cyclooxygenase inhibitory flavonoids from the stem bark of Semecarpus anacardium Linn. Phytother Res 8, 582-584

12. Bayer J, Gomer A, Demir Y, Amano H, Kish DD, Fairchild R, Heeger PS. (2004) Effects of green tea polyphenols on murine transplant-reactive T cell immunity. Clin Immunol 110, 100-108

13. Zhong Z, Connor HD, Froh M, Lind H, Bunzendahl H, Mason RP, Thurman RG, Lemasters JJ. (2004) Polyphenols from Camellia sinenesis prevent primary graft failure after transplantation of ethanol-induced fatty livers from rats. Free Radical Biol Med 36, 1248-1258

14. Manach C, Donovan JL. (2004) Pharmacokinetics and metabolism of dietary flavonoids in humans. Free Radical Res 38, 771-785 
15. Valachovicova T, Slivova V, Sliva D. (2004) Cellular and physiological effects of soy flavonoids. Mini Rev Med Chem 4, 881-887

16. Maxwell SRJ, Lip GYH. (1997) Reperfusion injury: A review of the pathophysiology, clinical manifestations and therapeutic options. Int J Cardiol 58, 95-117.

17. Urquiaga I, Leighton F. (2000) Plant polyphenol antioxidants and oxidative stress. Biol Res 33, 55-64.

18. Aherne SA, O’Brien NM. (2002) Dietary flavonoids: Chemistry, food content, and metabolism. Nutrition 18, 75-81

19. Veselá D, Kubínová R, Muselík J, Žemlička M, Suchý V. (2003) Antioxidative and EROD activities of osajin and pomiferin. Fitoterapia 75, 2029-211

20. Janoštíková E, Bartošíková L, Nečas J, Juřica J, Florian T, Bartošík T, Klusáková J, Suchý V, Lišková M, Frydrych M. (2005) Effects of pomiferin premedication on the antioxidant status of rats with ischemia-reperfused kidney. Acta Vet Brno 74, 557-564

21. Bartošíková L, Nečas J, Suchý V, Janoštíková E, Bartošík T, Juřica J, Florian T, Klusáková J, Frydrych M. (2006) Protective Effects of Osajin in Ischemia-Reperfusion of Laboratory Rat Kidney. Die Pharmazie 61, 552-555.
22. Vetchy D, Rabiskova M. (2002) Some variables influencing rotoagglomeration in the multiprocessor MP-1. Int J Pharm 242, 353-356

23. Kozlovski VI, Vdovichenko VP, Chlopicki S, Malcik SS, Praliyev ZD, Zcilkibayev OT. (2004) Antiarrhytmic profile and endothelial action of novel decanhydroquinoline derivatives. Pol J Pharmacol 56, 767-774

24. Buege JA, Aust SD. (1978) Microsomal lipid peroxidation. Method Enzymol 52, 302-309

25. Flohé L, Gunzler WA. (1984) Assays of glutathione peroxidase. Method Enzymol 105, 114-121

26. Kakkar P, Das B, Viswanathan PN. (1984) A modified spectrophotometric assay of superoxide - dismutase. Indian J Biochem Bio $21,130-132$

27. Spitz DR, Oberley LW. (1989) An assay for superoxide - dismutase activity in mammalian tissue homogenates. Anal Biochem 179, $8-18$

28. Wendel A. (1981) Glutathione peroxidase. Method Enzymol 77, 325-333

29. Kaneko M, Matsumoto Y, Hayashi H, Kobayashi A, Yamazaki N. (1994) Oxygen - free radicals and calcium homeostasis in the heart. Mol Cell Biochem 139, 91-100 